FACTA UNIVERSITATIS

Series: Physical Education and Sport, Vol. 18, No 2, 2020, pp. 483 - 490

https://doi.org/10.22190/FUPES200620046D

Research article

\title{
STUDENTS' PHYSICAL ACTIVITY LEVELS AT UNIVERSITY
}

UDC 796: 012.01

\author{
Branislav Dragić ${ }^{1}$, Emilija Petković ${ }^{1}$, Ana Lilić ${ }^{1}$, Marko Joksimović ${ }^{2}$ \\ ${ }^{1}$ Faculty of Sport and Physical Education, University of Niš, Niš, Serbia \\ ${ }^{2}$ Football Club Nacional, Podgorica, Montenegro
}

\begin{abstract}
The aim of this research was to determine the difference in the level of physical activity (PA) in students of four faculties of the University of Niš whose curricula do not include physical education (PE) classes. The PA level was evaluated using a questionnaire for the self-evaluation of PA (IPAQ-long form). The research included students of the Faculty of Philosophy, Faculty of Economics, Faculty of Law and Faculty of Electronic Engineering of the University of Niš $(n=109$; age: $22 \pm 0.6$ months). A significant difference was determined in the level of PA among the students of the University of Niš $(p=0.000)$. However, differences in PA during leisure time have not been determined $(p=0.109)$. One of the reasons is the active leisure time of the student population, which through sports activities compensates for the lack of PE classes at the faculties in question.
\end{abstract}

Key words: Students, Activity, IPAQ, Higher Education

\section{INTRODUCTION}

Physical activity (PA) induces the body to use its fat deposits (prevents overweight), increases the level of "good" cholesterol in the blood (HDL cholesterol) and maintains normal blood sugar levels. PA is the most natural means of spending energy and is an important regulator of body mass. During exercise, there is an intense energy metabolism, which leads to the creation of heat energy and the warming of the blood in the entire body, preventing an increase in body mass and obesity-related diseases. According to Bubanj \& Obradović (2002) regular physical exercise has a favorable effect on the work and functioning of the locomotor apparatus, strengthening the bones (it is reflected in the favorable level of calcium, which leads to an increase in bone density). The influence of appropriate PA on the respiratory system is great, since lung capacity increases and the oxygen uptake from the surrounding air is improved (Mazzeo \& Liccardo, 2019). It is known that of the $21 \%$ of oxygen (the amount

Received June 20, 2020 / Accepted July 18, 2020

Corresponding author: Branislav Dragić

Faculty of Sport and Physical Education, University of Niš, Čarnojevića 10a, Niš, Serbia

Phone: + 38118510900 • E-mail: branislav.dragic@gmail.com

(C) 2020 by University of Niš, Serbia | Creative Commons License: CC BY-NC-ND 
in which it is found in the normal atmosphere) only $15-18 \%$ is used (Qi et al., 2019). A decrease in anxiety and depression is evident among individuals who have their own regular PA program, which has a favorable effect on mood, cheerfulness and a more stable psychological state (McDowell, Dishman, Gordon, \& Herring, 2019; Pascoe, \& Parker, 2019). PA influences the development of motor skills and abilities, which is a basis for their future improvement and application in life (Stanković, Veljković, Marković, \& Herodek, 2020). Achieving mature patterns regarding these skills cannot be left entirely up to the spontaneous process of maturation, and instead it is necessary to create possibilities for learning and practice (Gallanue \& Ozmun, 1998). An active way of life during childhood is directly beneficial for health in later years, and in that way an active child becomes an active adult who is exposed to a reduced risk of illness.

The Higher Education Law, which was adopted at the end of August 2005, introduced several changes to the higher education system of the Republic of Serbia: a) using the European Credit Transfer System and accreditation and quality assurance of study programs and higher education institutions. The previous duration of graduate studies at the Serbian universities was changed from four to six years. According to research conducted by the Center for Education Policy from Belgrade, statistical data show that the officially expected duration of studies in practice is often transformed into a much longer period of the average duration of studies (the time that elapsed from enrollment to college to graduation): for four-year studies the average duration of studies was 6.76, for five-year studies it was 7.51 years, and for six-year studies it was 7.62 years. The number of students dropping out of college, as well as the average length of study were unreasonably high, and the most frequently mentioned reasons for this situation were a rigid system of study and a large student load (Turajlić, Andrejić, Rudić, \& Todorović, 2004). According to Vukasović (2007) the estimated drop-out rate for studies in this period was 45 percent. This means that in the period before the Bologna process, only 55 percent of enrolled students finished their studies. A previous quantitative study Vukosavić (2007) determined factors such as student motivation, systemic (institutional and non-institutional) student support programs, parent or peer support and their impact on the effectiveness of studying as stumbling stones of low efficiency of studying. The Bologna study model in Serbia was conducted in "spartan conditions" without financial opportunities. The Bologna Declaration provided only cutbacks to education reform, but did not administratively restrict national universities. The inability to provide financial assistance to state universities was also reflected in the reduced number of hours of certain subjects that are considered socially useful and important in the countries of the European Union - the area of PA at the universities in Serbia. The University of Niš is one of the four universities in Serbia that does not have the a physical education (PE) course in its curriculum, which is one of the important factors for reducing the risk of contemporary diseases of the society: addiction, cardiovascular disease and obesity. Health risks which are tied into the PA of adolescents, middle-aged and elderly people primarily depend on one's state of health (previous injury, the quality of one's diet, obesity, current conditions), the level of fitness components (a sedentary or active individual), types of activity, intensity (appropriate for the functional capacity of the individual), as well as the duration and frequency of the activity. The available information indicates that moderate PA corresponds to $40-50 \%$ of heart frequency levels. It is connected to the relatively low risk of orthopedic and cardio-vascular complications. Injuries to the locomotor system represent a risk for high-intensity PA, which can sometimes be found in as many as $55 \%$ of the active participants included in an 
exercise program. The intensity, frequency and duration of the PA are directly connected to risk of injury (Tinetti \& Kumar, 2010). In the initial phases of exercise, if there is an overdose in recreational activities, pain may occur in the muscles, exhaustion may set in, or orthopedic injury might occur. Strenuous aerobic training offers low level of additional improvement to cardio-respiratory fitness and is connected to a high rate of injury (Tinetti \& Kumar, 2010). The fundamental role of PA can be the healing of chronic disease (Haskell et al., 2007), so the mortality rate can be decreased (Warren et al., 2010).

The aim of this research was to determine the difference in the level of PA among students of four faculties of the University of Niš whose curricula did not include PE classes. In the evaluation of activity levels the IPAQ-long form questionnaire was used.

\section{METHODS}

There are objective methods used to evaluate PA (the usage of accelerometers and pedometers, monitoring heart rate frequency, direct observation); and methods based on self-evaluation i.e., questionnaires, journal logs, daily recordings (Warren et al., 2010; Kisko et al., 2012).

The International Physical Activity Questionnaire (IPAQ) was developed in 1997 to evaluate the level of PA on a global level (Craig et al., 2003). The IPAQ questionnaire addresses and evaluates the level of frequency, duration and intensity of PA during a single week. The long form of the questionnaire is designed for adults aged 18-65 and is more informative than the short one: it includes activities for leisure time, around the home and garden, at work, PA related to commuting to work and back. The IPAQ has good reliability and validity results for 70 countries, and it is available in several languages (Hallal et al., 2010; Lee, Macfarlane, Lam, \& Stewart, 2011; Helou et al., 2017; Minetto et al., 2017).

Research into the evaluation of the PA of a population by using the IPAQ is quite plentiful (Ishikawa-Takata et al., 2008; Polito et al., 2016; Hwa Hsu et al., 2017). Polito et al. (2016) evaluated the PA of Italian people aged 18-50 by using the questionnaire developed for monitoring PA and inactivity in national frames. The results have shown that the participants were far more active at home and in the garden than when commuting, or during their leisure time. Classifying activities based on intensity revealed significant differences between the genders in terms of moderate and high-intensity PA; in addition, participants aged 18-30 indicated a lower level of PA than participants aged 40-50. It was concluded that the national strategy for increasing PA should in particular focus on the younger population.

The sample of participants includes 109 fourth-year students, aged $22 \pm 0.6$ months, from four different faculties of the University of Niš: the Faculty of Economics $(n=30)$, the Faculty of Electronic Engineering $(n=30)$, the Faculty of Law $(n=25)$ and the Faculty of Philosophy $(n=24)$. The participating students voluntarily agreed to fill out the Serbian version of the questionnaire (Serbian Institute of Sport and Sports Medicine, n.d.). The approval of the Ethics Committee of the University of Niš was obtained.

In initial data processing descriptive statistics were used. In order to determine the normality of the distribution, the Shapiro-Wilk test was used. The comparison of the level of PA was performed using a method for determining inter-group differences and an analysis of variance. To compare pairs of faculties, the non-parametric Kruskal-Wallis test was used. This test is analogous to the Mann-Whitney test, but also allows for a 
comparison of several independent groups per sample. The Kruskal Wallis test is used for all types of activities included in the questionnaire. In this way it was possible to determine whether there are significant differences in the levels of activity in different fields from the viewpoint of the overall PA over the course of a studied week.

In statistical analyses, the SPSS statistical package version 24 was used, at the $p \leq 0.05$ level of significance.

\section{RESULTS}

All indicators of IPAQ scoring protocols are presented as metabolic equivalents (MET) in hours per week. Compared activities are divided into four categories: activities at work, activities which include transportation, activities around the house and garden and leisure time activities (recreational activities, sport, etc.). Descriptive statistics are presented in Table 1.

Table 1 The descriptive parameters of students from the University of Niš

\begin{tabular}{llrrrrrrrr}
\hline Faculty & $\begin{array}{l}\text { Type of activity } \\
\text { (MET/Week) }\end{array}$ & $\mathrm{N}$ & Mean & Median & Min & Max & SD & Skew & Kurt \\
\hline Philosophy & Work & & & & & & & & \\
& Commute & 17 & 32.07 & 23.10 & 6.60 & 92.40 & 24.11 & 1.401 & 1.596 \\
& Household & 22 & 32.49 & 17.88 & 3.00 & 144.00 & 34.74 & 1.979 & 4.296 \\
& Free time & 23 & 107.75 & 83.80 & 6.60 & 370.60 & 109.42 & 1.233 & .588 \\
\hline Economics & Work & 2 & 22.69 & 22.69 & 12.38 & 33.00 & 14.58 & $/$ & $/$ \\
& Commute & 30 & 30.42 & 28.95 & 8.25 & 49.50 & 13.69 & .007 & -1.554 \\
& Household & 17 & 4.62 & 3.00 & 1.50 & 7.50 & 2.21 & .043 & -1.852 \\
& Free time & 29 & 38.94 & 35.10 & 9.90 & 78.20 & 16.70 & .675 & .356 \\
\hline Law & Work & 10 & 295.19 & 242.10 & 176.50 & 734.40 & 161.20 & 2.694 & 7.799 \\
& Commute & 25 & 49.73 & 46.20 & 6.60 & 261.30 & 50.39 & 3.294 & 13.432 \\
& Household & 25 & 31.79 & 18.00 & 1.50 & 130.00 & 33.76 & 1.700 & 2.357 \\
& Free time & 25 & 59.48 & 55.60 & 3.30 & 116.40 & 36.10 & .057 & -1.344 \\
\hline Electronic & Work & 7 & 86.78 & 108.00 & 1.33 & 147.80 & 56.46 & -.898 & -.891 \\
& Commute & 29 & 28.03 & 19.80 & 1.10 & 268.80 & 48.55 & 4.670 & 23.474 \\
& Household & 25 & 26.17 & 20.00 & 3.50 & 163.00 & 31.89 & 3.618 & 14.946 \\
& Free time & 28 & 60.34 & 24.38 & 3.30 & 279.00 & 75.21 & 2.049 & 3.506 \\
\hline
\end{tabular}

Legend: $\mathrm{N}$-number of participants who provided a response in this group of questions;

Mean-mean value; Median-median; Min-minimal value; Max-maximal value;

SD-standard deviation; Skew-skewness; Kurt-kurtosis.

Table 2 shows the values of the median of the groups presented in MET hours per week, as well as the values of the $95 \%$ confidence interval, which includes $50 \%$ of the data.

Table 3 presents the types of activities with their $p$-value. It can be noted that these values, except for leisure time activities, are statistically significant. 
Table 2 Physical activity of students from the University of Niš (in MET hours/per week)

\begin{tabular}{|c|c|c|c|c|c|c|}
\hline Faculty & & Work & Commute & Household & Free time & Total \\
\hline \multirow[t]{3}{*}{ Philosophy } & The median & 162.6 & 23.1 & 17.9 & 83.8 & 132.8 \\
\hline & $95 \%$ confidence int. & $(19.8-350.4)$ & $(16.5-46.2)$ & $(9.0-45.0)$ & $(23.1-130.8)$ & $(72.3-346.8)$ \\
\hline & Interquartile range & 254.4 & 31.4 & 36.2 & 116.7 & 304.9 \\
\hline \multirow[t]{3}{*}{ Economics } & The median & 22.7 & 29.0 & 3.0 & 35.1 & 72.1 \\
\hline & $95 \%$ confidence int. & (12.4-33.0) & $(19.8-41.2)$ & $(3.0-7.0)$ & $(31.1-47.6)$ & $(65.2-88.3)$ \\
\hline & Interquartile range & 1 & 29.7 & 4.0 & 21.5 & 27.8 \\
\hline \multirow[t]{4}{*}{ Law } & The median & 242.1 & 46.2 & 18.0 & 55.6 & 201.9 \\
\hline & 95\% confidence int. & (199.6- & & & & (138.9- \\
\hline & & 331.8) & $(39.6-46.2)$ & $(13.0-37.0)$ & $(31.6-83.4)$ & 354.6) \\
\hline & Interquartile range & 97.4 & 29.7 & 33.0 & 68.0 & 224.15 \\
\hline \multirow{3}{*}{$\begin{array}{l}\text { Electronic } \\
\text { Engineering }\end{array}$} & The median & 108.0 & 19.8 & 20.0 & 24.4 & 73.4 \\
\hline & $\begin{array}{l}\text { 95\% confidence int. } \\
\text { Interquartile range }\end{array}$ & $(1.3-147.8)$ & $(11.6-23.10)$ & $(12.0-25.0)$ & $(17.2-66.2)$ & $(47.9-124.2)$ \\
\hline & $\begin{array}{l}\text { The median } \\
95 \% \text { confidence int. }\end{array}$ & 110.8 & 14.9 & 15.9 & 55.7 & 117.3 \\
\hline \multirow{3}{*}{$\begin{array}{l}\text { Entire } \\
\text { sample }\end{array}$} & Interquartile range & 169.6 & 23.1 & 14.0 & 39.6 & 93.8 \\
\hline & The median & $(96.0-232.8)$ & $(21.6-34.7)$ & $(10.5-20.0)$ & $(31.6-54.2)$ & $(77.5-112.4)$ \\
\hline & 95\% confidence int. & 188.1 & 29.7 & 21.0 & 57.3 & 145.4 \\
\hline
\end{tabular}

Table 3 Kruskal-Wallis test of the inter-group differences of students from the University of Niš

\begin{tabular}{lccccc}
\hline Activities & Work & Commute & Household & Leisure time & Total \\
\hline $\mathrm{N}$ & 28 & 101 & 89 & 105 & 109 \\
Chi-square* & 13.066 & 12.964 & 27.752 & 6.047 & 23.973 \\
$p$ - value & .004 & .005 & .000 & .109 & .000 \\
\hline
\end{tabular}

Legend: $* \mathrm{df}=3$ in all the tests; $\mathrm{N}$-the number of participants per group

\section{DISCUSSION}

Programmed PA has a positive effect on the health of people. Not participating in programmed PA leads to pre-obesity, abdominal obesity and problems with physical and psychological health. The World Health Organization - WHO (1997) and the International Federation of Sports Medicine determined that one half of humanity is insufficiently physically active. Obesity has been declared a global epidemic as far back as some twenty years ago (WHO, 2000). If obesity were to emerge in childhood, it usually persists into adulthood and presents a risk factor for many mass non-contagious diseases (WHO, 2000; Janssen, Katzmarzyket, \& Ross, 2002) and leads to significant health and socioeconomic complications (Wolf, 2003).

The relationship between PA and quality of life is connected to a better mood, a more positive self-image, higher level of self-respect and self-efficiency, a decrease in psychological and physiological stress (Berger \& Motl, 2001), an experience of enjoyment and entertainment (Csikszentmihalyi \& Le Fevre, 1989) which can play an important role in how one experiences their quality of life. PA cannot be replaced and needs to become a crucial issue for a healthy lifestyle. However, quality of life does not directly depend on one's state of health. Some individuals live a quality life and are satisfied with their life choices, despite their ailing health. A positive connection between the level of PA and quality of life might motivate healthy individuals to be more physically active. PA can 
reduce the risk of chronic illnesses, and have a general tendency for individuals (Weinstein, 1989). According to Rejeski \& Mihalko (2001) quality of life is a conscious cognitive evaluation of satisfaction with one's life.

The results (Table 2) indicate that students from the Faculty of Economics are less physically active at work. These data were observed with only two participants, who were employed during their studies. That is a very small sample, so it must be taken into account only conditionally. Students from this faculty are less interested in participating in household activities. The students of the Faculty of Law take the lead in PA at work, while the students of the Faculty of Philosophy are active during their leisure time. The results point us in the direction of the conclusion that there are differences in the activities of students attending various faculties. Thus, it should be further determined whether these differences are statistically significant.

The results (Table 3) lead to the conclusion that students from four faculties have significantly different levels of PA, despite the fact that they do not have PE classes as part of their university curriculum. Based on their choice of faculty, statistically significant differences were determined $\left[\chi^{2}(3.10)=23.97, p=.00<0.01\right]$. Significant differences in the activities were noted in all types of activities except in leisure time PA. Significant differences in the activities were found in all types of activities (work $\mathrm{p}=.00$; commute $\mathrm{p}=.00$; household activities $\mathrm{p}=.00$ ). Leisure time $\mathrm{PA}$, which includes recreational and other types of sport and physical activities $(\mathrm{p}=.10)$ showed no signs of significant differences. A lack of statistical significance was indicated because students spend their free time in an active manner. The location of the University of Niš and sports-recreational facilities and centers which provide different services for students are motivating for students to be included in all active sports life activities.

\section{CONCLUSION}

The current collaboration between the Council of Europe and the Ministry of Education, Science and Technological Development of the Republic of Serbia in our country has resulted in projects which started in 2017. These projects refer to the field of higher education and are focused on tolerance, the struggle against discrimination, and corruption in the educational system. It was determined that the higher education reform in Serbia is not yet complete, and there is still room to adapt to the standards of the European Union. By adhering to these standards, young people will be given the opportunity to have a high-quality education. The Bologna process in higher education is still not complete. This refers to the inclusion of new technologies in the process of education, but it also neglects PE which is a part of the tradition of the Serbian people. The relationship towards PA in elementary and high school education differs drastically compared to university-level education, so there is need for systematic PA to be included, due to the circumstances of modern-day life, i.e., the problem of obesity, cardiovascular issues, changes in the skeletal-muscle system, which result in excessive obesity and depression. The preparation for any systematic solution to this problem in higher education must be preceded by studies of social relations. 
Acknowledgement: This research is a part of the project "Anthropological characteristics of children and youth of South East Serbia - situation and trend changes" of the Faculty of Sport and Physical Education, University of Niš, Republic of Serbia.

\section{REFERENCES}

Berger, B.G., \& Motl, R.W. (2001). Physical activity and quality of life. In R.N.

Bubanj, S., \& Obradović, B. (2002). Mechanical force and bones density. Facta Universitatis Series Physical Education and Sport, 1(9), 37-50.

Craig, C.L., Marshall, A.L., Sjostrom, M., Bauman, A.E., Booth, M.L., Ainsworth, B.E., et al. (2003). International Physical Activity Questionnaire: 12-contry reliability and validity. Med Sci Sports Exerc, 35(8), 381-1395

Csikszentmihalyi, M., \& Le Fevre, J. (1989) Optimal experience in work and leisure. Journal of Personality and Social Psychology, 5, 815-822.

Gallahue, D.L. \& Ozmun, J.C. (1998). Understanding motor development: infants, children, adolescents, adults. McGraw-Hill International editions: Health/physical education/recreation series. ISBN: 0697294870, 9780697294876

Hallal, P.C., Gomez, L.F., Parra, D.C., Lobelo, F., Mosquera, J., Florindo, A.A., et al. (2010). Lessons learned after 10 years of IPAQ use in Brazil and Colombia. Journal of Physical Activity and Health, 7(2), S259-S264.

Haskell, W., Lee, I.M., Pate, R., Poweli, K.E., Blair, S.N., Franklin, B.A., et al. (2007). PA and public health: updated recommendation for adults from the American Collage of Sport Medicine and the American Heart Association. Medicine and Science in Sports and Exercise, 39(8), 1423-1434.

Helou, K., El Helou, N., Mahfouz, M., Mahfouz, Y', Salameh, P., \& Harmouche-Karaki, M. (2017). Validity and reliability of an adapted Arabic version of the long International Physical Activity Questionnaire. BMC Public Health, 18(1), 49.

Hwa Hsu, C., Tung. H.H., Clinciu, D.L., Chen, L.K., Yin, W.H., Igbal, U., et al. (2017). Physical activity. A primary health quality determinant among community-dwelling geriatric women in Taiwan. Int. J Qual Health Care, 19, 1-5.

Lee, P.H., Macfarlane, D.J., Lam, T.H., \& Stewart, S.M. (2011). Validity of the International Physical Activity Questionnaire short form (IPAQ-SF): A systematic review. International Journal of Behavioral Nutrition and Physical Activity, 8, 115-126.

Ishikawa-Takata, K., Tabata, I., Sasaki, S., Rafamantanantsoa, H.H., Okazaki, H., Okubo, H., et al. (2008). Physical activity level in healthy free-living Japanese estimated by doubly labelled water method and International Physical Activity Questionnaire. Eur J Clin Nutr, 62(7), 885-891.

Janssen, I., Katzmarzyk, T.P., Ross, R. (2002). Body mass index, waist circumference and health risk. Evidence in support of current national institutes of health guidelines. Arch Intern Med, 162(18), 2074-2079.

Kisko, A., Dernarova, L., Kmec, J., Horlenko, O., Kishko, \& Shyp, A., (2012). Physical activity assessment: an overview of currently available methods and future trends, In: Đ. Miletić, Z. Grgantov, S. Krstulović, T. Bavčević, \& A. Kezić (Eds.), Proceedings book of the $4^{\text {th }}$ International Scientific Conference "Contemporary Kinesiology", (pp. 453-461). Split: Faculty of Kinesiology.

Mazzeo, F., \& Liccardo, A. (2019). Respiratory responses to exercise in sport. Sport Science, 12(1), 49-52.

McDowell, C.P., Dishman, R.K., Gordon, B.R., \& Herring, M.P. (2019). Physical activity and anxiety: a systematic review and meta-analysis of prospective cohort studies. American Journal of Preventive Medicine, 57(4), 545-556.

Minetto, M.A., Motta, G., Gorji, N.E., Lucini, D., Biolo, G., Pigozzi, F., et al. (2017). Reproducibility and validity of the Italian version of the International Physical Activity Questionnaire in obese and diabetic patients. J Endocrinol Invest., 41(3), 343-349.

Pascoe, M.C., \& Parker, A.G. (2019). Physical activity and exercise as a universal depression prevention in young people: A narrative review. Early Intervention in Psychiatry, 13(4), 733-739.

Polito, A., Intorre, F., Ciarapica, D., Barnaba, L., Tagliabue, A., Ferraris, C., et al. (2016). Physical activity assessment in an Italian adult population using the International Physical Activity Questionnaire. Obes Res Open J, 4(1), 1-10.

Qi, X., Chen, L., Zhang, L., Bai, C., Xin, H., \& Rao, Z. (2019). In situ FTIR study on real-time changes of active groups during lignite reaction under low oxygen concentration conditions. Journal of the Energy Institute, 92(5), 1557-1566.

Rejeski, W.J. \& MIhalko, S.L. (2001). Physical activity and quality of life in older adults. The Journals of Gerontology: Series A, 56(2), 23-35. 
Serbian Institute of Sport and Sports Medicine (n.d.). Srpska verzija IPAQ upitnika (Serbian version of the IPAQ questionnaire). Retrieved March 24.2020 at the World Wide Web: http://www.usms.rs/kontent/ stranicy/podaci_i_statistika_ipaq/upitnik.pdf. In Serbian

Stanković, S., Veljković, A.A., Marković, Ž., \& Herodek, K. (2020). The effects of regular classes and classes with additional exercises on students'motor abilities. Facta Universitatis Series Physical Education and Sport, 18(1), 219-228.

Tinetti, M. \& Kumar, C. (2010). The patient who falls: "It's always a trade-off". Journal of the American Medical Association, 303(3), 258-266.

Turajlić, S., Andrejić, M., Rudić, L., \& Todorović, Lj. (2004). Higher Education in Serbia. Belgrade: Ministry of Education and Sport.

Vukosavić, M. (2007). Higher Education and Social Stratification in Serbia 1990-2005. Unpublished master work. University of Aveiro.

Warren, J., Ekelund, U., Besson, H., Mezzani, A., Geladas, N., \& Vanhees, L. (2010). Assessment of physical activity - a review of methodologies with reference to epidemiological research: a report of the exercise physiology section of the European Association of Cardiovascular Prevention and Rehabilitation. European Journal of Cardiovascular Prevention and Rehabilitation, 17(2), 127-139.

Weinstein, N.D. (1989). Effects of personal experience on self - protective behavior. Psychological Bulletin, 105(1), 31-50.

World Health Organization (1997). Obesity-preventing and managing the global epidemic. Report of WHO consultation on obesity. (pp. 7-17). Geneva.

World Health Organization (2000). Health systems: Improving performance. The world health report 2000. Retrieved March 24.2020 at: http://apps.who.int/gb/archive/pdf_files/WHA53/ea4.pdf.

Wolf, Z. (2003). Exploring the audit trail for qualitative investigations. Nurse Educator, 28, 175-178.

\section{NIVO FIZIČKE AKTIVNOSTI STUDENATA NA UNIVERZITETU}

Cilj ovog istraživanja bio je da se utvrdi razlika u nivou fizičke aktivnosti (FA) studenata četiri fakulteta Univerziteta u Nišu. Predmet istraživanja je studentska populacija čiji nastavni programi ne uključuju časove fizičkog vaspitanju $(F V)$ na Univerzitetu bez uključenih nastavnih programa nastave FV. U proceni nivoa fizičke aktivnosti korišćen je upitnik za samovrednovanje fizičke aktivnosti (IPAQ-duža verzija). Istraživanje je obuhvatalo studente Filozofskog, Ekonomskog, Pravnog i Elektronskog fakulteta Univerziteta u Nišu ( $n=109$; starost: $22 \pm 0.6$ meseci). Utvrđena je značajna razlika u nivou FA među studentima Univerziteta u Nišu ( $p=0.000)$. Međutim, razlike u $F A$ tokom slobodnog vremena nisu utvrđene $(p=0.109)$. Jedan od razloga je aktivno provođenje slobodnog vremena studentske populacije, koja sportskim aktivnostima nadoknađuje nedostatak $F V$ na fakultetima.

Ključne reči: studenti, aktivnost, IPAQ upitnik, visoko obrazovanje 